\title{
Characterization and Partial Purification of a Factor from Uremic Human Serum That Induces Insulin Resistance
}

\author{
Michael L. McCaleb, Margaret S. I2zo, and Dean H. Lockwood \\ Endocrine-Metabolism and Renal Units, Department of Medicine, University of Rochester \\ School of Medicine and Dentistry, Rochester, New York 14642
}

\begin{abstract}
We have previously shown that the incubation of normal rat adipose tissue with sera from nondialyzed, nondiabetic uremic patients reduces the transport and metabolism of glucose, in the absence and presence of insulin. In this study insulinstimulated glucose metabolism by normal rat adipocytes was used as a bioassay to identify the resistance activity, assess the effect of chemical modification on it, and the clinical states associated with its production. The resistance activity was trypsin-labile and had an apparent isoelectric point between 6 and 7, but was not retained by either protein $A$ or concanavalin A columns. The insulin resistance activity was decreased by coincubation with the protein synthesis inhibitor, cycloheximide. Purification to greater than 200,000 -fold was attained by heating $\left(100^{\circ} \mathrm{C}\right)$ uremic serum, subjecting the supernatant to Sephadex G-25 chromatography and subsequent adsorption to DEAE at pH 7.8 and elution at pH 6.5. The partially purified resistance activity was retained within dialysis tubing of 1,000 mol wt cutoff but not within 2,000-mol wt cutoff. Hemodialysis of patients over 1 wk to 18 mo reduced significantly the amount of resistance activity in their sera. The resistance activity, present in most uremic patients, was not found in the sera of individuals with normal renal function but who were either obese, fasted, elderly or had type II diabetes mellitus. Thus, a circulating small molecular weight peptide, unique to uremia, induced insulin resistance by a protein synthesisdependent mechanism.
\end{abstract}

\section{Introduction}

Chronic renal failure results in multiple metabolic derangements, including resistance to insulin (1). Using the euglycemic insulin clamp, DeFronzo et al. (2) have shown the quantity of glucose taken up by peripheral tissues in response to insulin is reduced in uremia. Also, insulin stimulation of glucose uptake by skeletal muscle is decreased in uremic patients (3). Epididymal fat has a reduced ability to transport and metabolize glucose in response to insulin, using a rat model for chronic uremia (4). Similarly, the insulin stimulation of lipid synthesis by hepatocytes from these animals is blunted considerably (5). The three major target tissues are thus insulin resistant.

Address correspondence to Dr. Lockwood, Endocrine-Metabolism Unit. Dr. McCaleb's present address is Ayerst Laboratories, Department of Biochemistry, Princeton, NJ 08540.

Received for publication 13 March 1984 and in revised form 3 October 1984.

J. Clin. Invest.

(c) The American Society for Clinical Investigation, Inc.

0021-9738/85/02/0391/06 \$1.00

Volume 75, February 1985, 391-396
The glucose intolerance (6) and impaired utilization of glucose (2) are improved significantly after the uremic patients undergo hemodialysis. These observations have led to the suggestion that a circulatory factor(s) is responsible for inducing insulin resistance $(2,6)$. The incubation of a variety of tissues obtained from normal animals with whole $(4,7,8)$ or partially purified (9) sera, obtained from chronically uremic patients, inhibits basal uptake of glucose. The insulin stimulation of glucose uptake and metabolism by rat adipocytes is also reduced following preincubation with uremic human serum $(4,10)$. This occurs without an alteration of either insulin binding or the antilipolytic action of insulin $(4,10)$. A circulating factor(s) appears to be responsible for the insulin resistance since the cellular abnormality induced by the uremic serum is identical to that seen in adipose tissue from uremic rats (4, 10). There is no evidence that the resistance activity is either a small end-product metabolite or a known glucoregulatory hormone, such as glucagon, insulin, parathyroid hormone, cortisol or growth hormone (10). In this study, we have characterized several of the chemical properties and partially purified a factor associated with the insulin resistance of uremia. Additional studies have been performed to define the clinical states of insulin resistance in which the activity is present.

\section{Methods}

Materials. Male Sprague-Dawley rats were obtained from Charles River Laboratories, Wilmington, MA. Crystalline porcine insulin was a gift of the Eli Lilly \& Co., Indianapolis, IN. Worthington Biochemical Corp., Freehold, NJ, supplied crude collagenase (type 1) and Trypsin-L-1-tosylamido-2-phenylethyl-chloromethyl ketone (Ec.3.4.21.4) (256 U/mg). Bovine albumin fraction V (BSA) was obtained from Reheis, Kankakee, IL. Spectra/Por 6 dialysis tubing with a cutoff of either 1,000, 2,000, or 3,500 mol wt was supplied by Arthur Thomas Co., Philadelphia, PA. Trypsin inhibitor (Ovomucoid) type 11-0 and cycloheximide came from Sigma Chemical Co., St. Louis, MO. Pharmacia Fine Chemicals, Piscataway, NJ, supplied the Sephadex G-25 medium, concanavalin A-Sepharose, Polybuffer 74, and Polybuffer exchanger 94. Cellex-D anionic exchanger, Bio-gel P-6 and protein $A$ linked to Affi-gel 10 were obtained from Bio-Rad Laboratories, Richmond, CA. The liquid scintillation fluor Soluscint $O$ was obtained from National Diagnostics, Somerville, NJ.

Serum measurements. Urea nitrogen was determined by diacetyl monoxime colorimetric assay, creatinine by the picric acid reaction assay and glucose by the glucose oxidase method; all from Sigma Chemical Co. Serum immunoreactive insulin was measured by the double-antibody method of Amersham/Searle, Arlington Heights, IL, with an intraassay variability of $2.6 \pm 0.4 \mu \mathrm{U} / \mathrm{ml}$ (mean $\pm \mathrm{SE}$ ). The levels of serum constituents were determined on nondialyzed sera. The protein of purified fractions of uremic serum was determined by binding to Coomassie Blue (Bio-Rad Laboratories) using BSA as the standard. 
Patient characteristics. Samples of serum were obtained from 16 male and 12 female patients, who ranged in age from 27 to $88 \mathrm{yr}$ (mean $\pm \mathrm{SD}, 59 \pm 17 \mathrm{yr}$ ). Blood was drawn at various.times of the day, however, nearly always in the postabsorptive state. These patients were diagnosed as having uremia according to established criteria (11). Their ranges of urea nitrogen and creatinine levels were 49 to 236 (mean $\pm S D$, $125 \pm 48)$ and 3.7 to $23.5(8.9 \pm 4.5) \mathrm{mg} / \mathrm{dl}$, respectively. These patients were not receiving glucocorticoid treatment or any other drugs known to alter glucose tolerance. None of them had received hemodialysis therapy (unless otherwise stated). They did not have diabetes mellitus as determined by fasting plasma glucose levels $<140 \mathrm{mg} / \mathrm{dl}$ (12). Sera of the uremic patients were also shown to contain significant $(P$ $<0.01$ ) amounts of insulin resistance activity as determined by bioassay (described below) and defined previously (10). The inhibition of insulin responses produced by the sera of the uremic patients used in this study ranged from 9 to $37 \%$. Characteristics of the type II diabetic, obese, elderly, 36-h fasted, and control subjects are presented in Results. In addition, all of these latter subjects were known to be free of renal disease.

Bioassay. Control and uremic sera, or partially purified fractions thereof, were dialyzed $18 \mathrm{~h}\left(4^{\circ} \mathrm{C}\right)$ against Parker's medium 199 (100fold excess volume) using cellulose dialysis tubing of 1,000-mol wt cutoff (unless otherwise stated). Epididymal adipose tissue derived from male rats ( 180 to $230 \mathrm{~g}$ ) was pooled, minced, and preincubated for either 3 or $5.5 \mathrm{~h}$ with human serum or purified fractions thereof ( $50 \% \mathrm{vol} / \mathrm{vol}$ ), and medium 199 , which contained $1 \mathrm{~g} / \mathrm{dl} \mathrm{BSA}$ and 0.3 $\mathrm{mg}$ Hepes/ml (pH 7.4) using a humidified atmosphere of $95 \% \mathrm{O}_{2} / 5 \%$ $\mathrm{CO}_{2}$ at $37^{\circ} \mathrm{C}(10)$. The adipocytes were then isolated by collagenase digestion (13) in Krebs-Ringer phosphate (KRP) ${ }^{1}$ buffer, pH 7.4, that contained $3 \mathrm{~g} / \mathrm{dl}$ BSA. The cell suspensions were maintained in this buffer after the removal of collagenase by three washings. As noted previously (4), there was no difference in the action of insulin on adipocytes isolated from tissue preincubated with either medium 199 or control serum. The pretreated adipocytes were incubated at $37^{\circ} \mathrm{C}$ with $0.2 \mathrm{mM} \mathrm{D}-\mathrm{U}-\left({ }^{14} \mathrm{C}\right)$ glucose (sp act $\left.0.67 \mathrm{Ci} / \mathrm{mmol}\right)$ and insulin $(1,000 \mu \mathrm{U} / \mathrm{ml})$. After $90 \mathrm{~min}$ oxidation of glucose was determined by trapping ${ }^{14} \mathrm{CO}_{2}$ with ethanolamine:3-methoxyethanol: 1:2 (vol/vol) in a hanging well, and incorporation of glucose into total ${ }^{14} \mathrm{C}$-lipid by extracting with the nonaqueous liquid scintillation fluor and then counting the organic phase.

Because of the usual between day variation in the quantity of glucose utilization, the metabolism by cells pretreated with the experimental serum was always compared to that by cells pretreated with control serum. Using this standardized bioassay, an inhibition of insulin-stimulated glucose metabolism to $>9 \%$, i.e., 2.31 SD of control value, was considered a significant $(P<0.01)$ change of the insulin response (10). The percent of inhibition by a serum sample was significantly correlated $(r=0.95, P<0.001)$ with the percent of inhibition on repeated experiments (10).

Each batch of control serum was a pool of at least six control subjects. As reported (4) and shown in Table IV pretreatment of adipose tissue with all batches of control serum did not cause a significant alteration of glucose utilization in the bioassay.

Heat treatment. $4 \mathrm{ml}$ of serum $(\mathrm{pH} \mathrm{7})$ was heated $\left(100^{\circ} \mathrm{C}\right)$ for 5 min. The precipitate was resuspended with $2 \mathrm{ml}$ of KRP at $4^{\circ} \mathrm{C}$ using a plastic pipette and centrifuged at $20,000 \mathrm{~g}$ for $15 \mathrm{~min}$. The supernatant $(\sim 3 \mathrm{ml})$ was collected and tested using the bioassay. The remaining precipitate was again resuspended and found not to contain significant resistance activity using the bioassay (data not shown).

Trypsin treatment. Serum or heat-supernatant of serum was incubated with trypsin $(2 \mathrm{mg} / \mathrm{ml})$ for $1 \mathrm{~h}$ at $37^{\circ} \mathrm{C}(\mathrm{pH}, 7)$ and the digestion was terminated by the addition of $4 \mathrm{mg} / \mathrm{ml}$ of trypsin inhibitor. The digested sera were either tested in bioassay immediately or else dialyzed $18 \mathrm{~h}$ before testing.

1. Abbreviations used in this paper: pI, isoelectric points; KRP, KrebsRinger phosphate.
Affinity columns. Serum $(4 \mathrm{ml})$ was applied to a protein A-agarose column $(8 \mathrm{ml})$ equilibrated with $0.1 \mathrm{M}$ sodium phosphate buffer, $\mathrm{pH}$ 7.2. The adsorbed fraction was eluted with $1 \dot{M}$ acetic acid and protein was determined by measuring absorbance $(280 \mathrm{~nm})$. Fractions were dialyzed $18 \mathrm{~h}$ and examined by bioassay. The heat-supernatant derived from $4 \mathrm{ml}$ of serum was applied to a concanavalin A-Sepharose $(1 \mathrm{mI})$ column equilibrated with KRP, $\mathrm{pH}$ 7.4. The adsorbed fraction was eluted with $0.3 \mathrm{M} \alpha$-methylmannoside in KRP, $\mathrm{pH} 7.4$, and eluted protein was determined by measuring absorbance at $280 \mathrm{~nm}$. Collected fractions were dialyzed and tested in bioassay.

Chromatofocusing. Before subjecting the heat-supernatant to chromatofocusing, the samples were first dialyzed (1,000-mol wt cutoff) against $25 \mathrm{mM}$ imidazole at $\mathrm{pH}$ 7.4. Polybuffer $74(\mathrm{pH} \mathrm{4.5)}$ was then used to elute the samples through a column of Polybuffer Exchanger 94 ( $\mathrm{pH} 7.4$ ) providing a pH gradient of 7.4 to 4.5. Retained proteins (isoelectric points $[\mathrm{pI}]<4.5$ ) were eluted with $1 \mathrm{M} \mathrm{NaCl}$. Fractions were dialyzed and subjected to routine bioassay.

Partial purification of factor. The heat supernatant $(\sim 3 \mathrm{ml})$ of either control or uremic serum was applied to a column $(1.2 \times 45$ $\mathrm{cm}$ ) of Sephadex G-25 medium equilibrated with $30 \mathrm{mM}$ ammonium bicarbonate, $\mathrm{pH}$ 7.40. The column was eluted with the same buffer at a flow rate of $35 \mathrm{ml} / \mathrm{h}$ and fractions $(1.0 \mathrm{ml})$ were collected. The fractions were then pooled, dialyzed, and tested using the bioassay. Alternatively, G-25 eluant containing resistance activity was applied immediately to the DEAE anion exchange column ( $1 \mathrm{ml}$ of Cellex-D) equilibrated with $30 \mathrm{mM}$ ammonium bicarbonate, $\mathrm{pH}$ 7.8. The DEAEeluant was reapplied. The fractions were eluted at decreasing $\mathrm{pH}$ by 1 $\mathrm{ml}$ of $30 \mathrm{mM}$ ammonium bicarbonate, pH 5.0 (adjusted with $\mathrm{HCl}$ ). Eluants were dialyzed and bioactivity determined the next day.

\section{Results}

Chemical characteristics of the factor. Heating the uremic serum at $100^{\circ} \mathrm{C}$ for $5 \mathrm{~min}$, at neutral $\mathrm{pH}$, did not alter the amount of resistance activity. However, digestion of the serum or the heat-supernatant with trypsin for $1 \mathrm{~h}$ completely eliminated all resistance activity (Table I). This coupled with the observation that the activity was precipitated with ammonium sulfate (data not shown) suggested that the factor(s) had a protein component. Since many serum proteins are asparaginelinked glycoproteins, we determined whether or not the activity could be removed by passing the serum through a glycoprotein affinity column of conconavalin $\mathrm{A}$. The resistance activity was not retained by the column of conconavalin A or by a column of protein A (data not shown). The resistance activity was destroyed by extremes of $\mathrm{pH}$, e.g., $<3$ or $>12$, but it was stable within the $\mathrm{pH}$ range of 5 to 9 . The apparent $\mathrm{pI}$ of the factor as determined by chromatofocusing was between 6 and 7 .

In three separate experiments, the inhibition induced by uremic serum increased from 6 to $9 \%$ and then to $26 \%$ as the time of preincubation was lengthened to 1,3 , and $5.5 \mathrm{~h}$, respectively. Significant inhibition was obtained only at the 3and 5.5-h times of preincubation. Because this suggested that the effect required a prolonged exposure, we examined the effect of blocking protein synthesis. The addition of a protein synthesis inhibitor, cycloheximide $(0.1 \mathrm{mM})$, to the preincubation medium prevented completely the inhibitory action of uremic serum. The cycloheximide did not alter the insulin responsiveness of tissue preincubated with control serum (insulin-stimulated total glucose utilization was $9.1 \pm 0.6$ vs. $8.8 \pm 0.4$ $\mathrm{nmol} / 10^{5}$ cells per $90 \mathrm{~min}$ in the absence or presence of cycloheximide, respectively).

As noted (10) the resistance activity was fully retained when uremic serum was dialyzed using 3,500-mol wt cutoff 
Table I. Characteristics of Insulin Resistance Factor from Uremic Human Serum

\begin{tabular}{lc}
\hline Treatment & $\begin{array}{l}\text { Initial } \\
\text { inhibitory activity }\end{array}$ \\
\hline & $\%$ \\
Heat: $100^{\circ} \mathrm{C}, 5 \mathrm{~min}(5)^{*}$ & $87 \ddagger$ \\
Trypsin: $2 \mathrm{mg} / \mathrm{ml}, 37^{\circ} \mathrm{C}, 1 \mathrm{~h}(5)$ & 8 \\
Conconavalin A column: not absorbed (6) & $102 \ddagger$ \\
pH change: $3(2)$ & 0 \\
$12(2)$ & 10 \\
Chromatofocusing: apparent pl 6 to $7(4)$ & $80 \ddagger$ \\
Cycloheximide $(0.1 \mathrm{mM})$ during bioassay (4) & 16
\end{tabular}

* See Methods for experimental details. Number of separate experiments are given in parentheses.

$\ddagger$ There was significant $(P<0.01)$ inhibition in every experiment performed.

tubing. However, as shown in Table II, after the serum was heat-treated the activity was no longer retained within the 3,500-mol wt cutoff tubing. It should be noted, that the activity in the serum from a sixth patient was retained within the 3,500-mol wt tubing. The reason for this aberrancy is unknown, but was replicated in a subsequent assay. Dialysis of the heattreated serum (heat supernatant) using tubing of 2,000-mol wt cutoff produced the same results using the sera from four different patients. The resistance activity was retained completely, however, within dialysis tubing of $1,000-\mathrm{mol}$ wt cutoff suggesting a molecular weight between 1,000 and 2,000.

Partial purification of the resistance activity. The stability of the resistance activity during heat-treatment was used as the first step of purification since $\sim 98 \%$ of the initial serum proteins were removed by heating and subsequent centrifugation (Table III). This step was also important because heat treatment appears to release the inhibitory activity from a larger $(>3,500)$ molecular weight substance(s) (see Table II), which interfered with our initial attempts of purification (data not shown).

The heat supernatant of uremic serum was subjected to gel chromatography using a small column of Sephadex G-25.

Table II. Estimation of Molecular Size of Insulin Resistance Activity

\begin{tabular}{llllc}
\hline & & & \multicolumn{2}{l}{ Resistance activity $\ddagger$} \\
\cline { 4 - 5 } Treatment before dialysis* & & $\begin{array}{l}\text { Cutoff of } \\
\text { dialysis tubing }\end{array}$ & $\begin{array}{l}\text { Pre- } \\
\text { treatment }\end{array}$ & $\begin{array}{l}\text { Post- } \\
\text { treatment }\end{array}$ \\
\hline & & $m o l w t$ & $\%$ & $\%$ \\
None (whole serum) & $(3)$ & 3,500 & $19 \pm 6 \S$ & $18 \pm 6 \S$ \\
Heat-supernatant & $(5)$ & 3,500 & $20 \pm 3 \S$ & $0 \pm 1$ \\
Heat-supernatant & $(4)$ & 2,000 & $17 \pm 3 \S$ & $3 \pm 2$ \\
Heat-supernatant & $(5)$ & 1,000 & $17 \pm 2 \S$ & $19 \pm 4 \S$
\end{tabular}

* See Methods for experimental details. Number of separate experiments is given in parentheses.

¥ Inhibition of insulin-stimulated glucose utilization produced by 4 $\mathrm{ml}$ of uremic serum per standard bioassay.

$\S$ There was significant $(P<0.01)$ inhibition in every experiment performed.
Table III. Purification of Insulin Resistance Activity from Serum of Uremic Humans

\begin{tabular}{|c|c|c|c|c|}
\hline Step* & $\begin{array}{l}\text { Units of } \\
\text { activity }\end{array}$ & Protein & $\begin{array}{l}\text { Specific } \\
\text { activity }\end{array}$ & $\begin{array}{l}\text { Fold } \\
\text { purification }\end{array}$ \\
\hline & & $m g$ & $\begin{array}{l}U / m g \\
\text { protein }\end{array}$ & \\
\hline I Whole serum & $1.0 \ddagger$ & 286.0 & 0.003 & - \\
\hline 2 Heat-Supernatant & 0.92 & 5.4 & 0.170 & 57 \\
\hline 3 Sephadex G-25 & 0.67 & $\sim 0.002$ & $\sim 335.0$ & $\sim 111,667$ \\
\hline 4 DEAE & 0.67 & $<0.001$ & $>670.0$ & $>223,333$ \\
\hline
\end{tabular}

* See Methods for experimental details.

$\ddagger$ Inhibition $(19 \pm 1 \%$ ) of insulin-stimulated glucose utilization produced by $4 \mathrm{ml}$ of uremic serum per standard bioassay.

As shown in Fig. 1, the resistance activity did not elute in the total included volume $\left(V_{\mathrm{t}}=40 \mathrm{ml}\right)$ but required a volume of 49-55 ml. A similar elution pattern of bioactivity occurred using a Bio-gel P-6 column (data not shown). It should be noted that most of the material eluting after the $V_{t}$, which exhibited absorbance at $280 \mathrm{~nm}$, was removed by dialysis (1,000-mol wt cutoff). The peak of resistance activity contained only $\sim 2 \mu \mathrm{g}$ of protein, as determined by Coomassie Blue protein assay. No significant amount of activity was found at any other elution volume or in fractions obtained from control serum.

This elution pattern suggests a nonspecific interaction of the activity with the gel and provided a convenient and efficient purification step (Table III). The eluants from the G25 columns were applied directly to a column of DEAEcellulose equilibrated at $\mathrm{pH}$ 7.8. All of the bioactivity was eluted from the DEAE as the $\mathrm{pH}$ was lowered to 6.5 using 30 $\mathrm{mM}$ ammonium bicarbonate at pH 5.0 (Table III). This was consistent with an apparent pI of 6 to 7 as determined by chromatofocusing (Table I). The DEAE-eluant, which contained $<1 \mu \mathrm{g}$ of detectable protein, possessed approximately two thirds of the initial resistance activity. Purification to greater than 200,000-fold was thus obtained with a minimal loss of bioactivity. In four experiments, the 3-h preincubation of adipose tissue with culture media containing either $20 \%$ (vol/ vol) or $40 \%$ of the DEAE-eluant produced either a $6 \pm 6 \%$ or $17 \pm 2 \%(P<0.01)$ inhibitory response, respectively.

The content of known glucoregulatory hormones was determined in the DEAE-eluant obtained from both control and uremic serum. The quantity of each substance examined, cortisol, parathyroid hormone, growth hormone, glucagon, free fatty acids, dopamine, norepinephrine and epinephrine, was below detectable levels (i.e., $<1 \mu \mathrm{g} / \mathrm{dl},<1 \mathrm{ng} / \mathrm{ml},<1$ $\mathrm{ng} / \mathrm{ml},<25 \mathrm{pg} / \mathrm{ml},<50 \mu \mathrm{eq} / \mathrm{ml},<41 \mathrm{pg} / \mathrm{ml},<38 \mathrm{pg} / \mathrm{ml}$ and $<21 \mathrm{pg} / \mathrm{ml}$, respectively).

Clinical states associated with the factor production. The sera from 10 uremic patients, before they had undergone any hemodialysis therapy, produced a $19 \pm 3 \%$ inhibition of insulinstimulated glucose utilization (Fig. 2). However, the maintenance of the patients on hemodialysis for periods of $1 \mathrm{wk}$ to 18 mo reduced significantly $(P<0.001)$ the amount of resistance activity present in their sera. The postabsorptive levels of serum insulin (mean $\pm \mathrm{SE}, 22 \pm 4$ to $19 \pm 2 \mu \mathrm{U} / \mathrm{ml}$ ) were not different but the levels of glucose $(116 \pm 8$ to $96 \pm 3 \mathrm{mg} / \mathrm{dl})$ were reduced significantly $(P<0.05)$. 


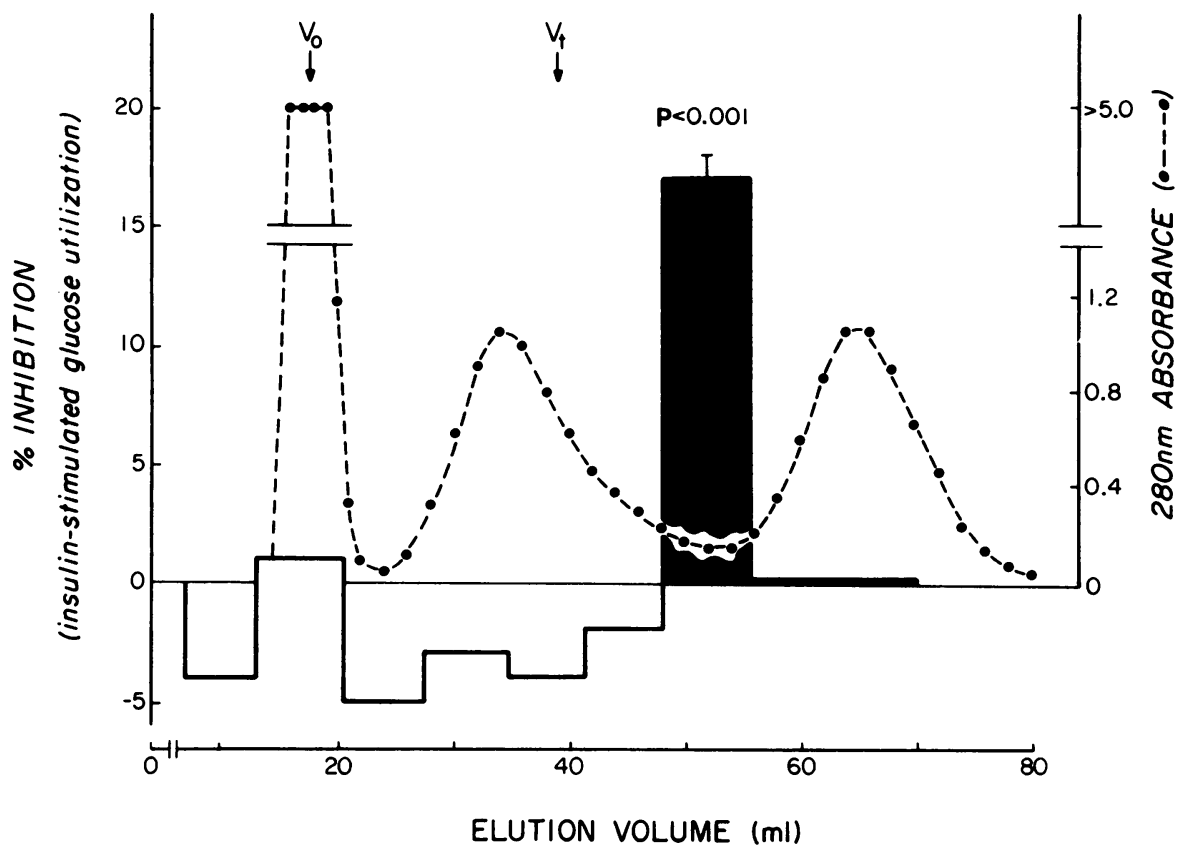

Figure 1. Insulin resistance activity in fractions of heat-treated uremic sera $(n=10)$ eluted from Sephadex G-25 columns. All fractions were assayed as described in Methods and response compared with that of tissue preincubated with fractions of control sera purified similarly. $V_{0}$, void volume of column; $V_{t}$, total included volume of column determined by $\left[{ }^{14} \mathrm{C}\right]$ glucose. Absorbance $(280 \mathrm{~nm})$ is shown for representative experiment.

The equivalent volumes of sera, obtained from individuals having normal renal function but who were either obese, 36$\mathrm{h}$ fasted, elderly, or had type II diabetes mellitus, were dialyzed (1,000-mol wt cutoff tubing) against culture medium and tested in the bioassay. As shown in Table IV, there were no indications that the sera from subjects having these insulinresistant states could induce the same inhibition as uremic serum. Even purification of these sera did not yield significant amounts of resistance activity. In addition, a 10-fold concentration of purified control serum did not alter insulin respon-

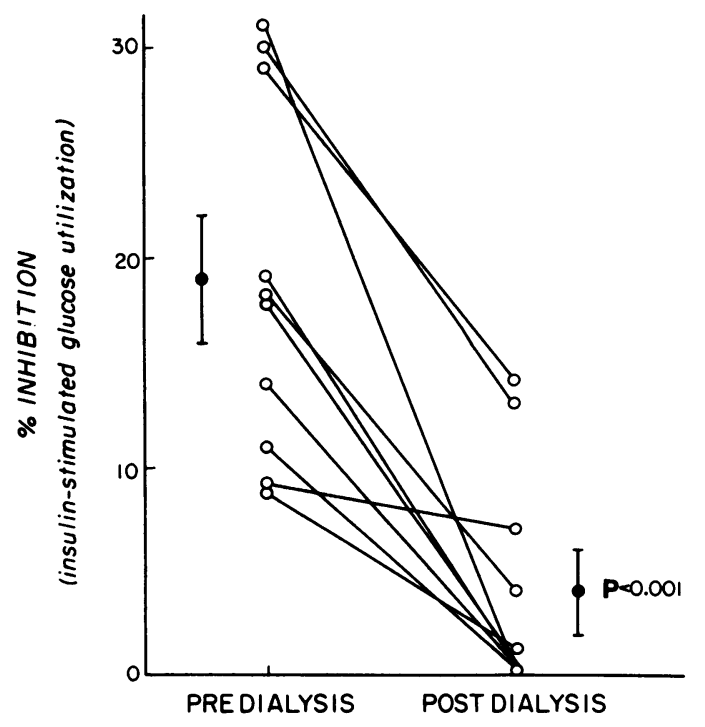

Figure 2. Effect of dialyzing uremic patients on presence of insulin resistance activity in serum. Insulin-stimulated glucose utilization by adipocytes prepared from tissue preincubated with uremic sera (obtained before patients were dialyzed) was inhibited significantly ( $P$ $<0.001)$ as compared with response of control-treated cells $\left(11.9 \pm 0.7 \mathrm{nmol} / 10^{5}\right.$ cells per $\left.90 \mathrm{~min}\right)$. The inhibitory activity in sera was then reduced significantly $(P<0.001)$ by dialysis of the 10 uremic patients. siveness $\left(9.2\right.$ and $9.4 \mathrm{nmol} / 10^{5}$ cells/90 min, using 4 or $44 \mathrm{ml}$ of serum, respectively).

\section{Discussion}

Multiple metabolic abnormalities associated with uremia have been attributed to circulating factors. Due to decreased clearance many metabolites as well as hormones and their fragments circulate at substantially elevated levels. There appears to be a composite of peptides in the molecular weight range of 1,000 to 5,000 , termed the "middle molecules," that may be particularly responsible for the pathologic sequelae of chronic renal failure (14). Several of these peptides have been well-characterized (14), but none have been directly shown to be responsible for inducing the insulin resistance associated with uremia (1). We have demonstrated $(4,10)$ that the serum of chronically uremic patients induces the same metabolic lesion in vitro as occurs with adipose tissue derived from uremic animals. In addition, fat from uremic rats can recover from an insulinresistant state when cultured for $20 \mathrm{~h}$ in a defined medium (4). This strongly supports the early hypothesis (6) that the insulin resistance associated with uremia is due to a circulating factor(s). Furthermore, we recently have found this factor to reduce insulin-stimulated amino acid uptake by primary cultures of hepatocytes (unpublished data).

We have now characterized this substance as a mildly acidic, heat-stable peptide with an estimated molecular weight between 1,000 and 2,000. Although we have not yet isolated it to purity, we have achieved substantial purification of at least 200,000-fold while retaining most of the biological activity. Importantly, as would be predicted $(2,6)$ there was a highly significant loss of insulin resistance activity in the sera of uremic patients after they had been maintained on dialysis therapy. This is further evidence that we have identified a substance from the blood of chronically uremic patients that is responsible for insulin resistance.

Consistent with previous reports $(2,6)$ the fasting serum insulin levels of the uremic patients remained elevated despite the hemodialysis therapy. However, as noted previously (2) 


\begin{tabular}{|c|c|c|c|c|c|c|}
\hline \multirow[b]{2}{*}{ Subjects } & \multirow[b]{2}{*}{ Age } & \multirow[b]{2}{*}{ Ideal body weight } & \multirow[b]{2}{*}{ Glucose } & \multirow[b]{2}{*}{ Insulin } & \multicolumn{2}{|c|}{ Insulin-stimulated total glucose utilization* } \\
\hline & & & & & Dialyzed serum & Purified serum \\
\hline & $y r$ & $\%$ & $m g / d l$ & $\mu U / m l$ & $\mathrm{nmol} \cdot 10^{5} \mathrm{cells} \cdot 90 \mathrm{~min}$ & \\
\hline Control (17)‡ & $26 \pm 4 \S$ & $98 \pm 10 \S$ & $89 \pm 14 \S$ & $15 \pm 3 \S$ & $10.2 \pm 1.6^{\prime \prime}$ & $9.1 \pm 0.2^{11}$ \\
\hline Buffer & & & & & $10.5 \pm 1.6$ & $9.1 \pm 0.5$ \\
\hline Obese (7) & $44 \pm 9$ & $179 \pm 25$ & $110 \pm 35$ & $29 \pm 9$ & $11.1 \pm 0.8$ & $11.0 \pm 1.3$ \\
\hline Control & & & & & $11.2 \pm 0.6$ & $9.8 \pm 1.1$ \\
\hline Type II DM (6) & $55 \pm 6$ & $138 \pm 28$ & $188 \pm 83$ & $30 \pm 16$ & $8.3 \pm 0.7$ & $10.7 \pm 1.0$ \\
\hline Control & & & & & $8.6 \pm 0.8$ & $9.8 \pm 0.9$ \\
\hline Fasting (3) & $29 \pm 1$ & $108 \pm 7$ & $71 \pm 8$ & $9 \pm 2$ & $9.9 \pm 1.7$ & $9.4 \pm 1.0$ \\
\hline Control & & & & & $9.9 \pm 1.9$ & $9.2 \pm 1.3$ \\
\hline Aged (6) & $74 \pm 2$ & $110 \pm 15$ & $80 \pm 11$ & $16 \pm 6$ & $8.7 \pm 1.0$ & NDף \\
\hline Control & & & & & $9.2 \pm 1.3$ & NDI \\
\hline
\end{tabular}

\footnotetext{
* See Methods for experimental details of bioassay. $¥$ Number of subjects is given in parentheses. $\S$ Data in this column are mean \pm SD.

"Data in this column are mean \pm SE. All values of insulin-stimulated total glucose utilization are not significantly different from paired control experiments. I Not determined.
}

dialysis did reduce the fasting concentration of glucose, which is indicative of improvement of insulin resistance.

The insulin resistance activity of uremia appears, at this time, to be unique for the uremic state. The activity is not present in equivalent amounts in the serum of subjects having such conditions of insulin resistance as obesity, type II diabetes mellitus, fasting, or aging; even when the serum was subjected to the same purification protocol as was done for uremic serum. In addition, there was no evidence of the activity in control serum that had undergone similar purification and subsequent concentration of 10 times the quantity of uremic serum usually used. Although several circulating substances have been suggested to be responsible for inducing the insulin resistance associated with other disease states, their chemical properties have been found to be different than this uremic factor. Notably, the historical insulin antagonists examined by Vallance-Owen (15) or Stetten and Field (16) differ in that they were either a basic peptide or a trypsin-stable and heatlabile protein, respectively. However, there are questions regarding the pathologic relevance of these factors (17). More recently, a trypsin-stable substance was identified in the blood of type II diabetic patients (18). This factor, which has an estimated molecular weight $<1,000$, reduced insulin-stimulated lipogenesis. Cerami et al. (19) have been examining a substance released from endotoxin-activated macrophages that inhibits insulin-stimulated lipoprotein lipase and lipogenesis. It does not, however, alter glucose transport (20). The production of this factor may explain the hyperlipidemia that occurs with infection. The macrophage factor was shown to be heat-labile and have a molecular weight $>12,000$ (19); both properties distinguish it from the uremic factor. Dzurik (9) has purified from uremic serum a peptide that alters basal metabolism of glucose. To our knowledge there is no evidence that this substance inhibits insulin action. It nevertheless differs from the resistance activity described in this paper since it is a basic peptide that elutes within the included volume of a Sephadex G-25 column (9). In addition, there is no evidence that the resistance activity is an identified glucoregulatory hormone
(10). It therefore seems that we have characterized a previously undescribed factor that induces insulin resistance.

The insulin resistance activity of uremia is most likely bound to a larger protein in vivo because of the results obtained after heat treatment. This is not an unexpected characteristic of small molecular weight substances that circulate in normal and pathologic states. We have very little information regarding the characteristics of the binding protein. Initial attempts at purification of the resistance activity from whole serum by ammonium sulfate precipitation and Amicon filtration were unsuccessful because bioactivity was inconsistently dispersed in multiple fractions (data not shown). This suggests several proteins may bind the activity. Also, since alterations of serum binding proteins during uremia are common (21, 22), there may be a carrier protein(s) unique to uremia.

Previously we demonstrated that the serum factor inhibits both transport and metabolism of glucose by rat adipocytes $(4,10)$. However, the antilipolytic action of insulin was unchanged (10). We have no evidence that the binding of insulin to its receptor on adipose tissue is altered either during chronic uremia or by the serum resistance activity (10). The insulin receptor on human monocytes (23), rat hepatocytes (24) and rat soleus muscle (25) also are not reduced during chronic uremia. It appears that the insulin resistance is due to a postbinding defect. Furthermore, the decrease of insulin-stimulated glucose utilization (insulin resistance activity) cannot be explained as a change of basal glucose response alone. As discussed (10), the mean decrease in basal glucose utilization $\left(0.4 \mathrm{nmol} / 10^{5}\right.$ cells per $\left.90 \mathrm{~min}\right)$, at $0.2 \mathrm{mM}$ glucose, accounted for only part of the $2.2 \mathrm{nmol}$ of inhibition in the presence of insulin (10).

The insulin resistance activity of uremia appears to have an intriguing mechanism by which it inhibits insulin action intracellularly. Co-incubation of the uremic serum with the protein synthesis inhibitor, cycloheximide, completely blocked the resistance activity. Protein synthesis is similarly required for the glucocorticoid analogue, dexamethasone, to inhibit insulin action (26). It will be of interest in the future to 
determine if the newly synthesized proteins induced by the uremic serum and dexamethasone are similar. Such proteins may be common and important cellular regulators of insulin responsiveness.

\section{Acknowledgments}

The authors wish to thank D. Saile for technical assistance and Drs. R. B. Freeman, Z. R. Freedman, T. E. Talley, and J. B. Wish for providing serum samples.

This investigation was supported by U. S. Public Health Service grant AM20129.

\section{References}

1. DeFronzo, R. A., R. Andres, P. Edgar, and W. G. Walker. 1973. Carbohydrate metabolism in uremia: a review. Medicine (Rochester). 52:469-481.

2. DeFronzo, R. A., J. D. Tobin, J. W. Rowe, and R. Andres. 1978. Glucose intolerance in uremia. J. Clin. Invest. 62:425-435.

3. Westervelt, F. B. 1968. Abnormal carbohydrate metabolism in uremia. Am. J. Clin. Nutr. 21:423-425.

4. Maloff, B. L., M. L. McCaleb, and D. H. Lockwood. 1983. Cellular basis of insulin resistance in chronic uremia. Am. J. Physiol. 245:E178-E184.

5. Caro, J. F., and S. Lanza-Jacoby. 1983. Insulin resistance in uremia. J. Clin. Invest. 72:882-892.

6. Hampers, C. L., J. S. Soeldner, P. B. Doak, and J. P. Merrill. 1966. Effect of chronic renal failure and hemodialysis on carbohydrate metabolism. J. Clin. Invest. 45:1719-1731.

7. Balestri, P. L., P. Rindi, M. Biagini, and S. Giovannetti. 1972. Effects of uraemic serum, urea, creatinine and methylguanidine on glucose metabolism. Clin. Sci. 42:395-404.

8. Morgan, J. M., and R. E. Morgan. 1964. Study of the effect of uremic metabolites on erythrocyte glycolysis. Metab. Clin. Exp. 13:629635.

9. Dzurik, R. 1980. Metabolic alterations caused by uremia. Proc. Eur. Dial. Transplant Assoc. 17:577-586.

10. McCaleb, M. L., R. Mevorach, R. B. Freeman, M. S. Izzo, and D. H. Lockwood. 1984. Induction of insulin resistance in normal adipose tissue by uremic human serum. Kidney Int. 25:416-421.

11. International Committee for Nomenclature and Nosology of Renal Disease. 1975. A Handbook of Kidney Nomenclature and
Nosology: Criteria for Diagnosis, Including Laboratory Procedures. Boston, Little, Brown and Co.

12. National Diabetes Data Group. 1979. Classification and diagnosis of diabetes mellitus and other categories of glucose intolerance. Diabetes. 28:1039-1057.

13. Rodbell, M. J. 1964. Metabolism of isolated fat cells. I. Effects of hormones on glucose metabolism and lipolysis. J. Biol. Chem. 239:375-380.

14. Bergstrom, J., P. Furst, and L. Zimmerman. 1979. Uremic middle molecules exist and are biologically active. Clin. Nephrol. 11:229-238.

15. Vallance-Owen, J., and M. D. Lilley. 1961. An insulin antagonist associated with plasma-albumin. Lancet. I:804-806.

16. Field, J. B., F. Tietze, and D. Stetten, Jr. 1957. Further characterization of an insulin antagonist in the serum of patients in diabetic acidosis. J. Clin. Invest. 36:1558-1593.

17. Davidson, M. B., and P. L. Poffenbarger. 1970. Role of synalbumin insulin antagonist in pathogenesis of diabetes mellitus. Metab. Clin. Exp. 19:668-686.

18. Dean, B., I. Peluso, and L. C. Harrison. 1984. A postbinding inhibitor of insulin action. Increased concentrations in the plasma of non-insulin-dependent diabetic subjects. Diabetes. 33:450-454.

19. Kawakami, M., P. H. Pekala, M. D. Lane, and A. Cerami. 1982. Lipoprotein lipase suppression in 3T3-L1 cells by an endotoxininduced mediator from exudate cells. Proc. Natl. Acad. Sci. USA. 79:912-916.

20. Pekala, P., M. Kawakami, W. Vine, M. D. Lane, and A. Cerami. 1983. Studies of insulin resistance in adipocytes induced by macrophage mediator. J. Exp. Med. 157:1360-1365.

21. Reidenberg, M. M., and M. Affrime. 1973. Influence of disease on binding of drugs to plasma proteins. Ann. NY Acad. Sci. 226:115126.

22. Shoeman, D. W., D. M. Benjamin, and D. L. Azarnoff. 1973. The alteration of plasma proteins in uremia as reflected in the ability to bind diphenylhydantoin. Ann. NY Acad. Sci. 226:127-130.

23. Smith, D., and R. A. DeFronzo. 1982. Insulin resistance in uremia mediated by postbinding defects. Kidney Int. 22:54-62.

24. Kauffman, J. M., and J. F. Caro. 1983. Insulin resistance in uremia. J. Clin. Invest. 71:698-708.

25. Smith, D., and R. A. DeFronzo. 1983. Insulin, glucagon and thyroid hormone. Renal Endocrinol. 11:367-428.

26. Livingston, J. N., and D. H. Lockwood. 1975. Effect of glucocorticoids on the glucose transport system of isolated fat cells. $J$. Biol. Chem. 250:8353-8360. 